\title{
Induction of Antibodies to Nuclear Antigens in Rabbits by Immunization with Hydralazine-Human Serum Albumin Conjugates
}

\author{
Yasutaka Yamauchi, Allen Litwin, Louis Adams, Hans Zimmer, and \\ Evelyn V. Hess \\ From the University of Cincinnati Medical Center, Department of Internal \\ Medicine, Division of Immunology, Cincinnati, Ohio 45267
}

\begin{abstract}
A B STRACT The antihypertensive drug hydralazine can induce in man a syndrome similar to spontaneous systemic lupus erythematosus (SLE). The pathogenesis of this drug-induced syndrome is not understood. In this investigation, five groups of rabbits were studied: group I, 10 rabbits hyperimmunized with hydralazine conjugated to human serum albumin (HSA) in complete Freund's adjuvant (CFA); group II, four rabbits with HSA in CFA; group III, four rabbits with CFA alone; group IV, five rabbits with hydralazine conjugated to rabbit serum albumin (RSA); and group V, four rabbits with a major metabolite of hydralazine conjugated to HSA. The rabbits immunized with hydralazine-HSA developed rising titers of antibodies to hydralazine and progressively increasing amounts of antibodies to both single-stranded and native DNA. The antibodies to DNA were cross-reactive with hydralazine as determined by inhibition of DNA binding and DNA hemagglutination tests. Similar results were obtained in rabbits immunized with the metabolite-HSA compound except the major hapten antibody response was to the metabolite. The DNA antibodies in this group were also capable of being absorbed by metabolite-HSA as well as hydralazine-HSA, indicative of the cross-reactivity between hydralazine and its metabolite. Immunization with hydralazine-RSA caused rabbits to produce antibodies to hydralazine but not to DNA, indicating the requirement for an immune response to the carrier protein in order for antibodies reactive with DNA to be produced. Thus, hyperimmunization of rabbits with hy-
\end{abstract}

This work was presented in part at the Central Society for Clinical Research, Chicago, November 1973.

Dr. Yamauchi's present address is: Department of Medicine, University of Kobe School of Medicine, Kusunokicho, Kobe, Japan.

Received for publication 25 July 1974 and in revised form 9 June 1975. dralazine-protein conjugates may provide a useful animal model of SLE. The data suggests that an immune response to hydralazine may be important in human hydralazine-induced SLE.

\section{INTRODUCTION}

In the large majority of patients with systemic lupus erythematosus (SLE), ${ }^{1}$ no specific etiological factor can be identified. However, after the administration of certain drugs, a small number of patients develop symptoms and signs which closely resemble those found in SLE. This drug-induced syndrome differs from spontaneous SLE primarily by a lack of central nervous system and renal involvement, an increased incidence in males, a very low to negligible incidence in blacks, and remission when the inciting drug is withdrawn $(1,2)$. Many of the serological stigmata of SLE are found in these patients including lupus erythematosus (LE) cells, antinuclear antibodies (ANA), antibodies directed against single-stranded DNA, and occasionally, in small amounts, antibodies against native DNA $(2,3)$. Even with the occurrence of clinical remission, serological abnormalities, including ANA, may persist for years (4). Although death is rare in drug-induced SLE, the few patients who have been autopsied have pathological findings similar to those found in spontaneous $\operatorname{SLE}(5,6)$. Even with the differences noted, the similarities between drug-induced and spontaneous SLE are sufficient to make the drug-induced variety a valid study model for SLE. Hydralazine, an antihypertensive

\footnotetext{
${ }^{1}$ Abbreviations used in this paper: ANA, antinuclear antibodies; B, bone marrow-derived; BSA, bovine serum albumin; HSA, human serum albumin; LE, lupus erythematosus; PBS, phosphate-buffered saline; RSA, rabbit serum albumin; SLE, systemic lupus erythematosus; T, thymusderived.
} 
agent, is one of the major drugs which can induce an SLE-like syndrome. It does so in approximately $7-13 \%$ of the patients chronically treated $(7,8)$. However, though we know the provocative agent, the possible pathogenetic mechanisms remain obscure with the sole exception that hydralazine antibodies have been reported in these patients $(3,9)$.

Unfortunately, to date animal experiments with hydralazine have not proven any more illuminating than human studies. Indeed, many conflicting results have been obtained. Even in experiments where ANA and/or LE cells were produced, pathological findings were equivocal or no data were provided to account for the production of serological findings.

Recently, we have succeeded in covalently binding hydralazine and one of its major urine metabolites (10) to human serum albumin (HSA) and rabbit serum albumin (RSA). The present study was undertaken to evaluate the immunological and pathological effects produced by immunization of rabbits with these compounds.

\section{METHODS}

New Zealand white rabbits weighing $1.5 \mathrm{~kg}$ initially and fed standard Purina rabbit chow were used in this study. For 24-h urine collections, the rabbits were placed in metabolic cages with free access to water and the urines collected for 24, 48, and, in some cases, $72 \mathrm{~h}$. The 24-h urinary total protein excretion was measured by the method of Shevky and Stafford (11).

Synthesis of the compounds of hydralazine and HSA and RSA were as follows: a solution of $p$-nitrophenol pyruvate hydralazone $\left(1.4 \mathrm{mg}, 4.0 \times 10^{-8} \mathrm{M}\right)$ in $0.5 \mathrm{ml}$ of tetrahydrofurane was added via a syringe to a stirred solution of HSA $\left(276 \mathrm{mg}, 4 \times 10^{-6} \mathrm{M}\right.$ ) (Miles Laboratories, Inc. Kankakee, Ill.) in $5.0 \mathrm{ml}$ of $\mathrm{pH} 9.2$ borax buffer $(0.025$ $\mathrm{M})$ at room temperature. The cloudy solution was stirred at room temperature until it became clear (about $90 \mathrm{~min}$ ) and allowed to stand at $4^{\circ} \mathrm{C}$ for $16 \mathrm{~h}$. Purification was accomplished by prolonged dialysis $\left(4-7\right.$ days) at $4^{\circ} \mathrm{C}$ against several changes of $2 \mathrm{~N}$ sodium chloride solution, followed by several changes of $\mathrm{pH} 8.2$ phosphate buffer ( 5 $\times 10^{-3} \mathrm{M}$ ) until complete removal of $p$-nitrophenol was achieved. At this time, the dialysates did not indicate the presence of the phenol according to UV analysis. Lyophilization of the dialysates was carried out, resulting in a light yellow powder. The extent of conjugation was estimated from the UV spectrum at $353 \mathrm{~nm}$. By using the extinction coefficient of the pyruvic acid hydralazone at $353 \mathrm{~nm}$, the number of residues of the hydralazone was calculated to be about 1 . By using appropriate amounts of the pyruvic acid hydralazone in the above procedure, conjugates were prepared with binding ratios of $1: 1,3: 1$, $6: 1,15: 1$, and $25: 1$. Similarly, a conjugate was paired with RSA (Miles Laboratories, Inc.) with a binding ratio of $25: 1$. These compounds will be referred to subsequently as "hydralazine-HSA" and "hydralazine-RSA." The subscript with hydralazine will refer to the number of moles of hapten per mole of carrier.

The main urinary metabolite of hydralazine is 3-methyl$s$-triazolo[3,4-a]phthalazine (12). Since this molecule does not possess a functional group via which it could be co- valently conjugated to $\mathrm{HSA}$ or RSA, it was structurally altered slightly to permit it to be chemically bound to a protein. The compound chosen for this purpose was 2-(striazolo[3,4-a]phthalaziny1) propionic acid (13). Conjugation was achieved in a manner similar to the above method. Thus, to a solution of HSA, $500 \mathrm{mg}\left(7.25 \times 10^{-6}\right.$ $\mathrm{M})$ in $50 \mathrm{ml}$ of $\mathrm{pH} 9.2$ borax buffer was added to powdered 4-nitrophenyl 2-(3-s-triazolo[3,4- $\alpha]$ phthalazinyl propionate), $68 \mathrm{mg}\left(1.94 \times 10^{-4} \mathrm{M}\right)$. The mixture was stirred $48 \mathrm{~h}$ at room temperature and buffered. The filtrate was concentrated by lyophilization and purified as above. The extent of conjugation was estimated by analysis of the UV spectrum of the conjugate. The extinction coefficient of the substituted propionic acid at $241 \mathrm{~nm}\left(4.33 \times 10^{3}\right)$ was used. The binding ratio of triazolophthalazine per molecule of HSA was calculated to be about $6: 1$. In an analogous manner, the RSA conjugate was prepared. These compounds will be referred to subsequently as "metabolite-HSA" and "metabolite-RSA." The subscript with metabolite will refer to the number of moles of hapten per mole of carrier.

Various molar ratios of hydralazine conjugated to HSA were tested for immunogenicity before the present experiments. The compounds tested ranged from hydralazine ${ }^{-}$ HSA to hydralazine $e_{2}-$ HSA. The latter proved the most immunogenic as measured by precipitating antibodies. At the start of the experiment, the highest molar ratio of metabolite to HSA that could be synthesized was $6: 1$, and a compound with this ratio was used in these experiments as an immunogen. Later, higher molar ratios could be achieved and metabolite ${ }_{15}$-RSA was used as described below for determining hydralazine metabolite antibodies.

Hydralazine antibodies were determined by microadaptation of the passive hemagglutination test of Boyden with tanned sheep red blood cells coated with hydralazine $25-\mathrm{RSA}$ $(14,15)$. As all rabbits in each group failed to recognize RSA immunologically, this test measured only antihydralazine antibodies. Antibodies to metabolite ${ }_{6} \mathrm{HSA}$ were measured in similar fashion except that the sheep erythrocytes were coated with metabolite ${ }_{15}-\mathrm{RSA}$. Inhibition studies were performed by adding $50 \mu \mathrm{g}$ of the inhibitor to each well on the microtiter plate and then carrying out the titer as above. The compounds used for inhibition included hydralazine $\mathrm{HCl}$, hydralazinie ${ }_{25}-\mathrm{RSA}$, hydralazine ${ }_{25}-\mathrm{HSA}$ and metabolite 15 -RSA.

Anti-DNA antibodies were measured by a modification of the binding assay of Carr et al. with $\left[{ }^{3} \mathrm{H}\right]$ actinomycinD-labeled calf thymus DNA for antibodies against both single-stranded and native DNA (16). Briefly, highly polymerized calf thymus DNA (Worthington Biochemical Corp., Freehold, N. J.) was labeled with $\left[{ }^{3} \mathrm{H}\right]$ actinomycin $\mathrm{D}$ (sp act $3.8 \mathrm{Ci} / \mathrm{mmol}$ ) (Schwarz/Mann Div., Becton, Dickinson \& Co., Orangeburg, N. Y.). For binding to native DNA, $0.05 \mathrm{ml}$ of dialyzed labeled native DNA (50 $\mu \mathrm{g}$ ) was incubated with $0.1 \mathrm{ml}$ of the rabbit serum to be tested and $0.85 \mathrm{ml}$ phosphate-buffered saline (PBS), $\mathrm{pH}$ 7.4 , at $37^{\circ} \mathrm{C}$ for $1 \mathrm{~h}$ and then for $24 \mathrm{~h}$ at $4^{\circ} \mathrm{C}$. Then an equal volume of saturated ammonium sulfate was added and the mixture stirred vigorously for $30 \mathrm{~min}$. The resulting precipitate was centrifuged at $900 \mathrm{~g}$ for $1 \mathrm{~h}$ and then washed once again with half-saturated ammonium sulfate. The washed precipitate was dissolved in $1.5 \mathrm{ml}$ of Soluene-350 (Packard Instrument Co., Inc., Downers Grove, Ill.) and $12 \mathrm{ml}$ of scintillation fluid (PPO and POPOP in toluene) and counted in a liquid scintillation counter (Mark-II, Amersham/Searle Corp., Arlington Heights, Ill.). Incubation for longer than $24 \mathrm{~h}$ did not 
increase the percent binding obtained. For measurement of binding antibodies to single-stranded DNA, native calf thymus DNA (Worthington Biochemical Corp.) was heat denatured by being placed in boiling water for $10 \mathrm{~min}$ and then rapidly cooled in ice. The single-stranded DNA was then labeled with $\left[{ }^{3} \mathrm{H}\right]$ actinomycin $\mathrm{D}$ and, after dialysis, 0.1 $\mathrm{ml}$ of the single-stranded DNA preparation $(100 \mu \mathrm{g})$ was mixed with $0.1 \mathrm{ml}$ of the serum to be analyzed and $0.8 \mathrm{ml}$ of $1 \mathrm{M}$ phosphase-buffered $\mathrm{NaCl}, \mathrm{pH}$ 7.4. Samples were first incubated at $37^{\circ} \mathrm{C}$ for $30 \mathrm{~min}$ and then for $24 \mathrm{~h}$ at $4^{\circ} \mathrm{C}$ and then processed as described above. Inhibition studies were performed by incubating the serum before testing with the inhibitor at $37^{\circ} \mathrm{C}$ for $1 \mathrm{~h}$ and then at $4^{\circ} \mathrm{C}$ for $23 \mathrm{~h}$. Any precipitate after incubation was removed by centrifugation. Deproteinized native calf thymus DNA (Sigma Chemical Company, St. Louis, Mo.) was prepared according to the method of Marmur (17) and then labeled with $\left[{ }^{3} \mathrm{H}\right]$ actinomycin $\mathrm{D}$ as described above and used for detection of antibodies to native DNA with sera obtained from the final bleedings.

To exclude the possibility that the antibodies being detected by the "native" DNA-binding assay were not to the small areas of single-strandedness known to exist in commercial DNA $(18,19)$ but to the double-stranded structure of native DNA, native DNA (Worthington Biochemical Corp.) was digested with an exonuclease isolated from Neurospora crassa conidia (Miles Laboratories, Inc.), an enzyme which has been demonstrated to be specific for single-stranded DNA (prepared by heat) and which does not attack DNA in the native form $(20,21) .3 \mathrm{mg}$ of native DNA dissolved in $0.1 \mathrm{M}$ Tris- $\mathrm{HCl}$ buffer, $\mathrm{pH} 8.0$, was incubated with $0.8 \mathrm{ml}$ of $0.6 \mathrm{M}$ Tris- $\mathrm{HCl}, \mathrm{pH} 8.0,0.8$ $\mathrm{ml} 0.06 \mathrm{M} \mathrm{MgCl}, 0.8 \mathrm{ml}$ of $100 \mathrm{U}$ of $N$. crassa exonuclease with a total reaction mixture of $4.8 \mathrm{ml}$ for $5 \mathrm{~h}$ at $37^{\circ} \mathrm{C}$. The digest was exhaustively dialyzed at $4^{\circ} \mathrm{C}$ against PBS. The DNA was then extracted with phenol and chloroform, precipitated with ethyl alcohol, and then dissolved and dialyzed against $\mathrm{PBS}$, thus freeing the DNA from the enzyme. A control preparation of DNA was treated in the same manner but without the enzyme, and, since there was no enzyme present, extraction and precipitation was not carried out. Both preparations were labeled with $\left[{ }^{3} \mathrm{H}\right]$ actinomycin D. Sera and IgG fractions from the various experimental and control groups were tested to detect differences in binding. To test the activity of the enzyme, single-stranded (heat-denatured) DNA was treated in a similar manner with the exonuclease as described for native DNA. Another tube containing single-stranded DNA kept under the same conditions served as a control for this experiment. $89 \%$ of the single-stranded DNA was destroyed by the exonuclease.

Precipitating antibodies against both calf thymus native and single-stranded DNA as well as native and singlestranded salmon sperm DNA (Sigma Chemical Co., St. Louis, Mo.) and M. lysodeikticus (Sigma Chemical Co.) native and single-stranded DNA were performed with $0.6 \%$ agarose gel in $0.15 \mathrm{M}$ PBS, $\mathrm{pH} 7.2$ (22). Inhibition of precipitating antibodies was performed by incubating the serum for $1 \mathrm{~h}$ at $37^{\circ} \mathrm{C}$ and then $23 \mathrm{~h}$ at $4^{\circ} \mathrm{C}$ with the inhibitor. After incubation, any precipitate was removed by centrifugation.

Hemagglutinating antibodies to native DNA were determined by the method of Inami et al. by using formalinized human type $O$ cells (23). RSA rather than bovine serum albumin (BSA) was used as a diluent as rabbits which made antibodies to HSA exhibited crossreactivity with BSA, which interfered with the test. Inhibition of this test was accomplished by placing $50 \mu \mathrm{g}$ of the inhibitor in each well of the microtiter plate before performing the test.

ANA were determined by using normal rabbit peripheral white cells as a substrate with a fluoresceinated goat antirabbit IgG antiserum at a concentration of $3 \mathrm{mg} / \mathrm{ml}$. The antiserum was prepared and labeled in this laboratory.

IgG fractions of sera from seven rabbits were purified by using DEAE-cellulose chromatography (24) and assessed for DNA binding activity and hydralazine hemagglutinins as described above.

All antibody assays were performed with serum heated at $56^{\circ} \mathrm{C}$ for $30 \mathrm{~min}$ with some repeated with the same serum heated at $56^{\circ} \mathrm{C}$ for $60 \mathrm{~min}$. The additional 30 -min heating did not produce any appreciable changes in the results.

At the time of sacrifice, tissues were taken for histopathological studies including routine hematoxylin and eosin and periodic acid-Schiff stains of the tissue sections. Some tissues were snap frozen for immunofluorescent studies.

The experimental design involved five (5) groups of rabbits. Group $I$ consisted of 10 rabbits immunized at 2 -wk intervals until the 12th wk with hydralazine 2 -HSA in complete Freund's adjuvant (CFA). One additional injection was given at the 17 th wk. The initial dose was 10 $\mathrm{mg}$ of hydralazine $\mathrm{s}_{5}-\mathrm{HSA}$ in CFA divided between the hind foot pads. Subsequent injections consisted of $5 \mathrm{mg}$ of hydralazine ${ }_{25}-\mathrm{HSA}$ in CFA injected subcutaneously into the back and neck. In group II, there were four rabbits immunized with HSA in CFA after a similar dosage and injection schedule. In group III were four rabbits which received CFA alone on a similar schedule. In group $I V$, five rabbits were immunized with hydralazine ${ }_{25}-\mathrm{RSA}$ in CFA after a similar dosage and injection schedule. Group $V$ consisted of four rabbits immunized with metabolite e $^{-}$ HSA again on a similar schedule and manner as the other groups. The data obtained from animals in groups II and III were similar and have been combined and referred to subsequently as the "controls." The mean and standard deviations for the DNA binding assays were determined by the unpaired $t$ test. A paired $t$ test was used to compare intragroup differences (25).

\section{RESULTS}

Fig. 1 shows the mean hydralazine antibody titer from each group. Only rabbits immunized with hydralazine $25-$ HSA, hydralazine $25-\mathrm{RSA}$, or metabolite ${ }_{-}$HSA developed significant titers of hydralazine antibodies as measured by hemagglutination. After the sixth injection, titers ceased to rise despite continuing immunization. When first measured at $4 \mathrm{wk}$, a time by which two injections had been administered, the antibody titers in the hydralazine $25-\mathrm{HSA}$, hydralazine $25-\mathrm{RSA}$, and the

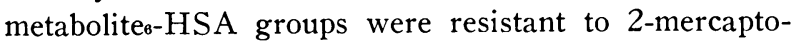
ethanol, indicating that the antibodies were primarily IgG. The antibody titers against hydralazine in the

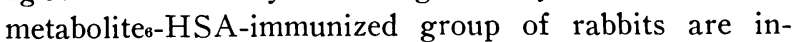
dicative of the cross-reactivity between hydralazine and its major urinary metabolite. Inhibition studies of the hydralazine antibody titers were done with the sera obtained at the termination of the experiment (22 wk) 
TABLE I

Hydralazine Metabolite Hemagglutinins Found in the Metabolite ${ }_{6}$-HSA-

Immunized Rabbits (Group V)*

\begin{tabular}{rrrrrrrr}
\hline & $\begin{array}{c}\text { Pre- } \\
\text { immuni- } \\
\text { zation }\end{array}$ & \multicolumn{1}{c}{ W } & \multicolumn{6}{c}{ Weeks after immunization } \\
\cline { 2 - 8 } Rabbit & 2 & 256 & 2,560 & \multicolumn{1}{c}{12} & \multicolumn{1}{c}{16} & 20 & 22 \\
\hline I-074 & 2 & 25,600 & 320,000 & 160,000 & 12,800 \\
I-075 & 0 & 64 & 640 & 2,560 & 2,560 & 6,400 & ND \\
I-076 & 0 & 64 & 160 & 320 & 640 & 3,200 & 3,200 \\
I-077 & 0 & 128 & 1,280 & 2,560 & 12,800 & 25,600 & 12,800 \\
\hline
\end{tabular}

* Reciprocal of the titer.

$\ddagger N D$, not done.

from the hydralazine ${ }_{25}-\mathrm{HSA}$ and the hydralazine 2 - RSA groups. Complete or almost complete inhibition of the titers was obtained with hydralazine 2 -RSA, hydralazine $25-\mathrm{HSA}$, and hydralazine $\mathrm{HCl}$ itself. Table I depicts the mean metabolite antibody titers found in group $\mathrm{V}$, the metabolite ${ }_{-}$-HSA-immunized rabbits. These titers were also resistant to 2-mercaptoethanol $4 \mathrm{wk}$ after immunization and were completely inhibited by metaboliteHSA. The hydralazine $25-$ HSA and the hydralazine $25-$ RSA

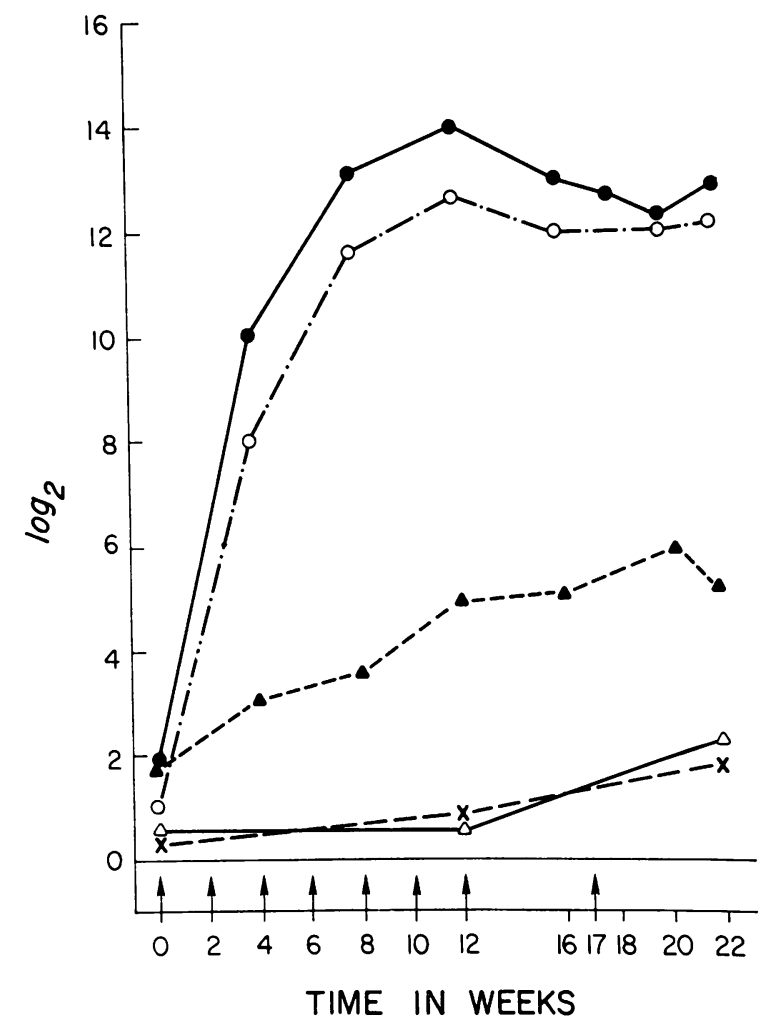

FIGURE 1 Hydralazine hemagglutinating antibody titers found in each group of rabbits. Hydralazine $25-\mathrm{HSA}$ $(\bullet-\bullet)$, HSA $(\triangle-\triangle)$, CFA $(X--X)$, hydralazine ${ }_{25}$ RSA $(\mathrm{O}-\cdot-\mathrm{O})$, and metabolite ${ }_{-}-\mathrm{HSA}(\boldsymbol{\Delta}--\boldsymbol{\Delta})$. Arrows indicate time of injection. groups of rabbits also had low titers of antibody to metabolite $15-\mathrm{RSA}$, again indicating the cross-reactivity that exists between hydralazine and its metabolite.

Fig. 2 illustrates the mean binding antibody titers to $\left[{ }^{3} \mathrm{H}\right]$ single-stranded calf thymus DNA. Significant binding is limited to the metabolite ${ }_{-}-\mathrm{HSA}$ and the hydralazine25-HSA groups. By the 4th wk, 4 rabbits in the latter group exceeded the mean $\pm 2 \mathrm{SD}$ of the controls, and by the 8 th wk, 9 of 10 did. The difference between the hydralazines-HSA group and the controls continued to increase until the 12th wk. The additional injection on the 17th wk produced a further rise in binding. Three of four rabbits immunized with metabolites-HSA exhibited significant binding by the 4 th $\mathrm{wk}$ and by the 12th wk, all four animals had binding that was significantly increased as compared to the controls. The position of the final point in Fig. 2 of the $22 \mathrm{wk}$ binding of

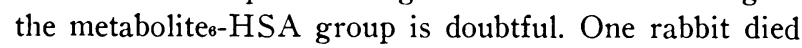
before being bled and at that time another rabbit which had had a small but significant amount of binding to single-stranded DNA no longer had detectable antibodies to single-stranded DNA. No response was noted in the hydralazine 2 -RSA group, implying a major role for the carrier protein in the production of DNA antibodies.

In the hydralazines-HSA group, 9 of 10 rabbits had precipitating antibodies at the $22 \mathrm{nd}$ wk of immunization to one or more of the various types of single-stranded DNA tested which included calf thymus, salmon sperm, and $M$. lysodeikticus. Precipitins to single-stranded DNA were detected in three of four of the metabolite HSA group of animals. These precipitin lines were not observed when the serum had been previously absorbed with single-stranded DNA.

The mean binding antibodies to $\left[{ }^{3} \mathrm{H}\right]$ calf thymus native DNA is seen in each group in Fig. 3. Only the hy-

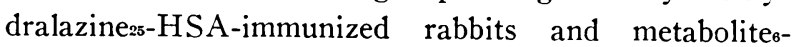
HSA rabbits show significant binding. In the former group, three rabbits had significantly elevated levels of antibodies to native DNA $4 \mathrm{wk}$ after beginning immuni- 


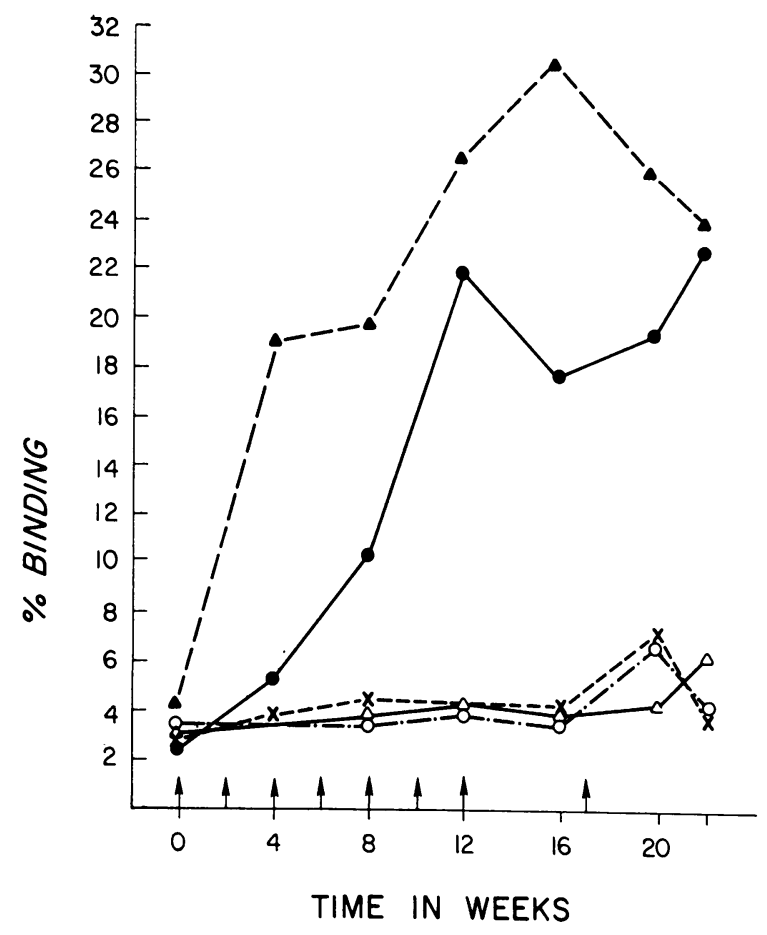

Figure $\left.2{ }^{3} \mathrm{H}\right]$ Single-stranded calf thymus DNA-binding assays in each group of rabbits. Hydralazine ${ }_{25}-\mathrm{HSA}$ $(\bullet-\bullet)$, HSA $(\triangle-\triangle)$, CFA $(X--\times)$, hydralazine $25-$ RSA $(\mathrm{O}-\cdot-\mathrm{O})$, and metabolite ${ }^{-} \mathrm{HSA}(\boldsymbol{\Delta}--\boldsymbol{\Delta})$. Arrows indicate time of injection.

zation. By $8 \mathrm{wk}$, six rabbits had some increase in binding although this was borderline in three. The amount of binding continued to rise in these six rabbits until by $22 \mathrm{wk}$, two had between 10 and $15 \%$ binding, three between 15 and $21 \%$ binding, and one $53 \%$ binding. The mean $\pm 2 \mathrm{SD}$ of the controls at this time was $6.3 \pm 1.8 \%$. By a paired $t$ test, the native DNA binding of the preimmunization sera compared to the 22-wk sera showed a significant increase for the group as a whole with a $P$ value of $<0.025$. The rise in antibodies to native DNA found in the metabolite-HSA animals was similar to that observed in the hydralazine 25 -HSA group of

TABLE II

Native DNA Hemagglutinin Titers

\begin{tabular}{ccccc}
\hline Rabbit & Group & $\begin{array}{c}\text { DNA } \\
\text { titer* }\end{array}$ & $\begin{array}{c}\text { DNA titer } \\
\text { after } \\
\text { inhibition* }\end{array}$ & $\begin{array}{c}\% \text { binding } \\
{\left[{ }^{3} \mathrm{H}\right] \text { native }} \\
\text { DNA }\end{array}$ \\
\hline I-093 & I & 32 & 2 & 19 \\
I-095 & I & 64 & 0 & 53 \\
I-096 & I & 16 & 2 & 15 \\
I-077 & V & 32 & 0 & 26 \\
I-074 & V & 8 & 0 & 12 \\
\hline
\end{tabular}

* Reciprocal of the titer.

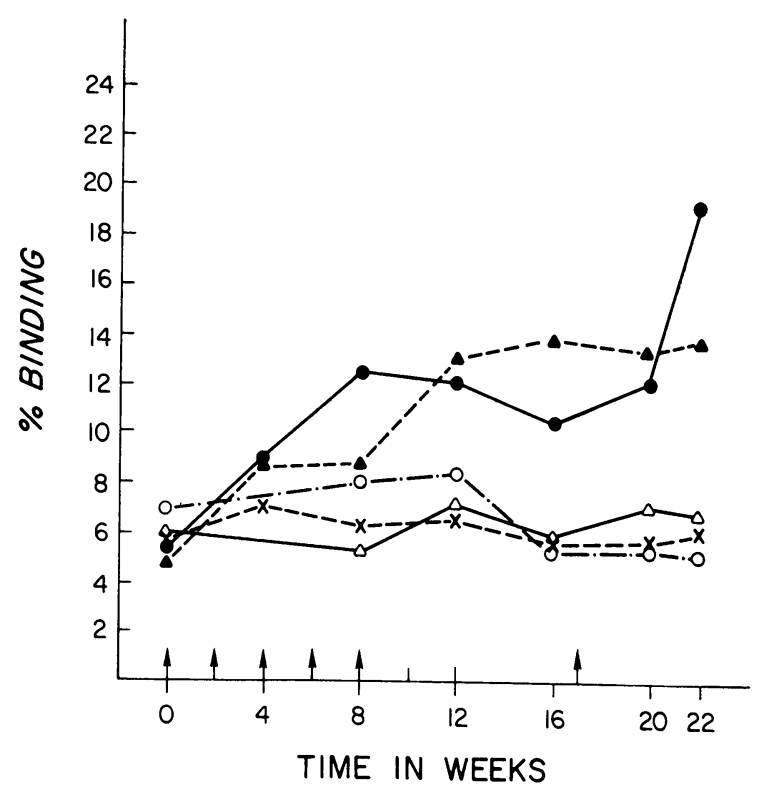

Figure $3\left[{ }^{3} \mathrm{H}\right]$ Native calf thymus DNA-binding assays in each group of rabbits. Hydralazine 25 -HSA ( - $\bullet$ ), HSA $(\triangle-\triangle)$, CFA $(X--\times)$, hydralazine 25 RSA $(O-\cdot-O)$, and metabolite ${ }_{6}$-HSA $(\boldsymbol{\Delta}--\boldsymbol{\Delta})$. Arrows indicate time of injection.

rabbits. By the 4th wk, two of four rabbits showed significant binding which persisted. The highest binding found in one of these rabbits was $29 \%$, noted in the 16 th wk; at the 20 th wk, it was $27 \%$, and at the $22 \mathrm{nd} \mathrm{wk}$, $26 \%$. The highest level in the other rabbit was $13 \%$. The sera obtained at the end of the experiment ( $22 \mathrm{wk}$ ) from all rabbits were treated with DNAase as described by Harbeck et al. to detect circulating DNA-anti-DNA complexes by observing a further increase in DNA binding after treatment with DNAase (26). This test was negative except in the one rabbit immunized with hydralazine $25-\mathrm{HSA}$, which had $53 \%$ binding with $\left[{ }^{3} \mathrm{H}\right]-$ calf thymus native DNA. In this instance, the binding rose an additional $20 \%$. Precipitating antibodies to native DNA were not detected by either system of immunodiffusion with serum from any rabbit. Similar values for binding were obtained with the highly purified deproteinized calf thymus native DNA.

Hemagglutinins to native DNA were determined only on the sera from the final bleed. These results are depicted in Table II. Only sera with a titer greater than $1: 4$ are represented in the table. Significant amounts of DNA hemagglutinins were detected in three rabbits immunized with hydralazine 25 -HSA and two rabbits im-

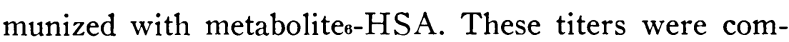
pletely or almost completely inhibited by calf thymus native DNA. Hemagglutinins to native DNA were not detected in any other rabbit. It is of interest that only

962 Y. Yamauchi, A. Litwin, L. Adams, H. Zimmer, and E. V. Hess 
TABLE III

Inhibition of ["II]Calf Thymus DNA-Binding Assays in Three Rabbits from the Hydralazine ${ }_{25}$-HSA-Immunized Rabbits (Group I, 22-wk Serum)*

\begin{tabular}{|c|c|c|c|c|c|}
\hline \multirow[b]{2}{*}{ Inlibitor } & \multirow{2}{*}{ 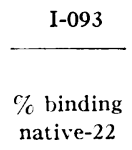 } & \multicolumn{2}{|c|}{ I-095 } & \multicolumn{2}{|c|}{$\mathrm{I}-098$} \\
\hline & & $\begin{array}{c}\% \text { binding } \\
\text { native-53 }\end{array}$ & $\begin{array}{l}\% \text { binding } \\
\text { single } \\
\text { stranded }-49\end{array}$ & $\begin{array}{l}\% \text { binding } \\
\text { native- } 27\end{array}$ & $\begin{array}{l}\% \text { binding } \\
\text { single } \\
\text { stranded }-62\end{array}$ \\
\hline Hydralazine $\mathrm{HCl}, 200 \mu \mathrm{g} / \mathrm{ml}$ & 76 & 83 & 90 & 87 & 95 \\
\hline Hydralazine $_{25}-\mathrm{HSA}, 1 \mathrm{mg} / \mathrm{ml}$ & 74 & 87 & 89 & 75 & 95 \\
\hline $\mathrm{HSA}, 1 \mathrm{mg} / \mathrm{ml}$ & 5 & 0 & 0 & 20 & 0 \\
\hline Hydralazine $_{25}-\mathrm{RSA}, 1 \mathrm{mg} / \mathrm{ml}$ & 86 & 88 & 84 & 99 & 93 \\
\hline $\mathrm{RSA}, 1 \mathrm{mg} / \mathrm{ml}$ & 0 & 0 & 0 & 25 & 0 \\
\hline
\end{tabular}

* Percent inhibition.

rabbits with the highest native DNA binding had positive DNA hemagglutinin tests.

Fig. 4 shows a double diffusion in agarose picture of a 22 -wk serum obtained from a hydralazine 25 -HSA-immunized rabbit reacted against hydralazine $25-\mathrm{RSA}$, two concentrations of single-stranded calf thymus DNA, and calf thymus native DNA. Two precipitin lines were produced to hydralazine $25-\mathrm{RSA}$ : an outer thicker line which shows no reaction with DNA and a thinner inner line which shows a reaction of identity with single-stranded calf thymus DNA. No precipitin line is seen to calf thymus native DNA. This unexpected finding suggested that there was a population of antibodies to hydralazine which was cross-reactive with single-stranded DNA. Similar precipitin in gel reactions were observed in the sera of several rabbits in the hydralazine $25-\mathrm{HSA}$ group with reaction of the inner line to hydralazine:s-RSA showing either complete or partial identity with singlestranded DNA. Absorption of the sera with single-

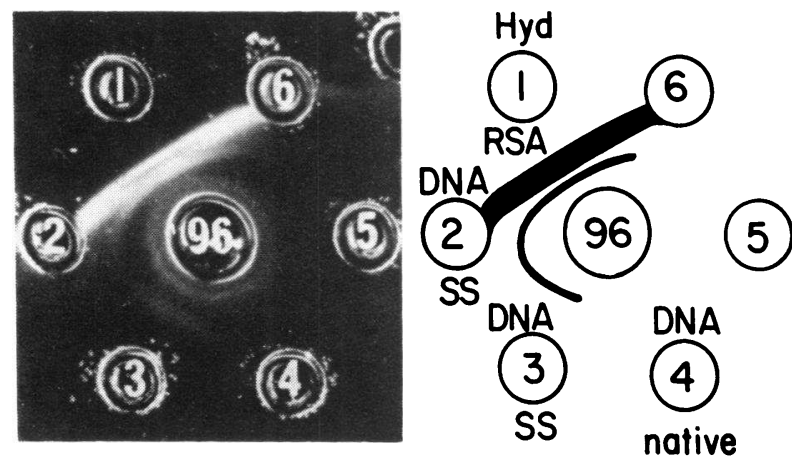

FIGURE 4 Double diffusion in agarose study of a 22-wk serum from a hydralazine $25-$ HSA-immunized rabbit (I-096). Center well contains the antiserum. Well 1 contains hydralazine $_{25}-\mathrm{RSA} 1 \mathrm{mg} / \mathrm{ml}$; well 2 calf thymus singlestranded DNA, $500 \mu \mathrm{g} / \mathrm{ml}$; well 3 calf thymus singlestranded DNA, $1 \mathrm{mg} / \mathrm{ml}$; well 4 calf thymus native DNA, $1 \mathrm{mg} / \mathrm{ml}$; and wells 5 and 6 normal saline. On the left is a photograph and on the right is a graphic representation. stranded DNA sometimes but not consistently resulted in loss of the inner line to hydralazines-RSA and always resulted in loss of the lines to single-stranded DNA. Confirmation of this suggested cross-reactivity of hydralazine with DNA was sought by a variety of inhibition tests. The $\left[{ }^{3} \mathrm{H}\right] \mathrm{DNA}$ calf thymus native and singlestranded binding assays were repeated after absorbing the serum with hydralazine $\mathrm{HCl}$, hydralazines- $\mathrm{RSA}$, hydralazine 2 -HSA, RSA, and HSA. The results found in three rabbits in the hydralazine 25 -HSA group are shown in Table III. Hydralazine and both of its compounds removed binding to both native and singlestranded DNA in all sera tested, whereas the carrier proteins produced no significant inhibition. Marked inhibition of both single-stranded and native calf thymus $\left[{ }^{3} \mathrm{H}\right]$ DNA binding was observed with as little as $20 \mu \mathrm{g}$ of hydralazine $\mathrm{HCl}$. As seen in Table IV, similar results were obtained with inhibition studies of native and single-stranded calf thymus $\left[{ }^{3} \mathrm{H}\right] \mathrm{DNA}$ binding in metabolite ${ }_{-}-\mathrm{HSA}$-immunized rabbits. In the three sera studied, there was significant inhibition of both types of binding by hydralazine $\mathrm{HCl}$, hydralazine ${ }_{25}-\mathrm{HSA}$, and metabolite-HSA, with the highest degree of inhibition

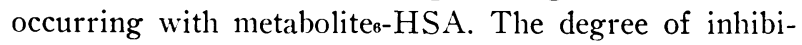
tion was not as striking as that found in the hydralazine 25 -HSA-immunized rabbits but was still marked, particularly in rabbit I-075. As the degree of inhibition of binding produced by hydralazines-HSA was almost as great as that found with metabolite ${ }_{-}-\mathrm{HSA}$ in the sera of these rabbits (group V), it seems likely that the antigenic determinant on hydralazine and its major metabolite that causes production of DNA antibodies is very likely a shared determinant. The native DNA hemagglutinating titers were completely inhibited by hydralaziness-RSA with the same sera from rabbits immunized with hydralazine 25 -HSA or metabolite ${ }_{-}$HSA. The reverse experiment was also attempted, i.e., inhibition of the hydralazine antibody titers with native DNA. In sera from the terminal bleed of the hydrala- 
TABLE IV

Inhibition of $\left[{ }^{3} \mathrm{H}\right]$ Calf Thymus DNA-Binding Assays in Three Rabbits from the Metabolite $_{6}$-HSA-Immunized Rabbits (Group V, Final Blecd)*

\begin{tabular}{|c|c|c|c|c|}
\hline \multirow[b]{2}{*}{ Inhibitor } & \multicolumn{2}{|c|}{$\mathrm{I}-077$} & \multirow{2}{*}{$\frac{\mathrm{I}-074}{\begin{array}{c}\% \text { binding } \\
\text { single } \\
\text { stranded-45 }\end{array}}$} & \multirow{2}{*}{$\begin{array}{c}\mathrm{I}-075 \\
\begin{array}{c}\text { binding } \\
\text { single } \\
\text { stranded-30 }\end{array}\end{array}$} \\
\hline & $\begin{array}{l}\% \text { binding } \\
\text { native-26 }\end{array}$ & $\begin{array}{l}\% \text { binding } \\
\text { single } \\
\text { stranded-41 }\end{array}$ & & \\
\hline Hydralazine $\mathrm{HCl}, 200 \mu \mathrm{g} / \mathrm{ml}$ & 51 & 57 & 41 & 73 \\
\hline $\mathrm{HSA}, 1 \mathrm{mg} / \mathrm{ml}$ & 10 & 0 & 4 & 0 \\
\hline Hydralazine $_{25}$-HSA, $1 \mathrm{mg} / \mathrm{ml}$ & 36 & 43 & 44 & 72 \\
\hline Metabolite $_{6}-\mathrm{HSA}, 1 \mathrm{mg} / \mathrm{ml}$ & 45 & 59 & 50 & 71 \\
\hline
\end{tabular}

* Percent inhibition.

zine25-HSA-immunized rabbits, the hydralazine titer was reduced by two tubes (twofold dilutions) in four rabbits, three tubes in one rabbit, and four dilutions in another rabbit. This last rabbit was the rabbit which had both the highest binding to native DNA and the highest hemagglutinin titer to native DNA. No inhibition with native DNA was observed in the hydralazine hemagglutinin titers found in the sera of the hydralazine $25-$ RSA-immunized rabbits. It is quite likely that the amount of hydralazine antibodies that cross-react with DNA is quite small in view of the relative thinness of the line against hydralazine $25-\mathrm{RSA}$, which cross-reacted with single-stranded DNA, the practically complete absorption of antibodies to both native and single-stranded DNA be extremely small amounts of hydralazine $\mathrm{HCl}$, and the minimal inhibition of the hydralazine hemagglutinins by native DNA in the hydralazine $25-\mathrm{HSA}$-immunized rabbits.

The sera in the hydralazine 25 -HSA group and the metabolite-HSA group were absorbed with various sources of single-stranded and native DNA. Binding activity to native DNA could be removed by prior incubation of the serum for $24 \mathrm{~h}$ with ntaive DNA and at times, single-stranded DNA, whereas single-stranded activity was primarily removed by the various single-stranded DNA's. Table V depicts typical inhibition patterns ob- tained with calf thymus DNA both in its native and singe-stranded forms as an inhibitor.

Tests for antinuclear factor were performed with sera obtained on the terminal bleed. These were positive in $8 / 10$ of the hydralazine 2 -HSA-immunized group and in $2 / 4$ of the metabolite ${ }^{-H S A}$ group. In the hydralazine $25-$ HSA group, six had a titer of at least $1: 8$ and two $1: 4$. In the metabolite - HSA group, both rabbits had a titer of $1: 8$. The titers were not taken to higher levels. The ests were negative in the controls and in the hydralaine 25 -HSA-immunized rabbits.

IgG fractions were isolated from the 22-wk sera of

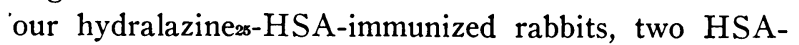
mmunized rabbits, and one CFA-immunized rabbit. The purity of the fractions was verified by immunoelectrophoresis against a goat anti-rabbit whole serum. The fractions were studied for hydralazine hemagglutinins and DNA binding activity with the results illustrated in Table VI. Only the fractions from the hydralazine $25-$ HSA-immunized rabbits had high titers of hydralazine antibodies and DNA binding activity, proving that both of these tests were mediated by an IgG antibody. The hydralazine antibody titers in the $\mathrm{IgG}$ fractions were disproportionately elevated as opposed to the titers found in the whole serum. The reason for this disproportionate elevation is not clear.

TABLE V

Inhibition of $\left[{ }^{3} H\right] D N A-B i n d i n g$ Assays*

\begin{tabular}{|c|c|c|c|c|c|c|c|}
\hline \multirow[b]{3}{*}{ Inhibitor } & \multicolumn{5}{|c|}{ Group I } & \multirow{2}{*}{\multicolumn{2}{|c|}{$\begin{array}{c}\text { Group V } \\
\mathrm{I}-077\end{array}$}} \\
\hline & \multirow{2}{*}{$\begin{array}{c}\mathrm{I}-093 \\
\begin{array}{l}\text { \% binding } \\
\text { DNA nat. } \\
22\end{array}\end{array}$} & \multicolumn{2}{|c|}{$\mathrm{I}-095$} & \multicolumn{2}{|c|}{ I-098 } & & \\
\hline & & $\begin{array}{c}\% \text { binding } \\
\text { DNA nat. } \\
53\end{array}$ & $\begin{array}{c}\% \text { binding } \\
\text { DNA }_{\mathrm{ss}} \\
\mathbf{4 1}\end{array}$ & $\begin{array}{c}\% \text { binding } \\
\text { DNA nat. } \\
\quad 22\end{array}$ & $\begin{array}{c}\text { \% binding } \\
\text { DNA }_{s s} \\
38\end{array}$ & $\begin{array}{c}\% \text { binding } \\
\text { DNA nat. } \\
26\end{array}$ & $\begin{array}{c}\% \text { binding } \\
\text { DNA }_{\mathrm{ss}} \\
41\end{array}$ \\
\hline DNA nat., $1 \mathrm{mg} / \mathrm{ml}$ & 100 & 55 & 18 & 100 & 15 & 68 & 19 \\
\hline $\mathrm{DNA}_{\mathrm{ss}}, 1 \mathrm{mg} / \mathrm{ml}$ & 0 & 34 & 40 & 0 & 18 & 0 & 39 \\
\hline
\end{tabular}

DNA nat., calf thymus native DNA; DNA

* Percent inhibition. 
TABLE VI

$\left[{ }^{3} \mathrm{H}\right]$ Calf Thymus DNA Binding and Hydralazine Hemagglutination Titers of Whole Serum and IgG Fractions $(2 \mathrm{mg} / \mathrm{ml})$ from Four Rabbits Immunized with Hydralazine ${ }_{25}-$ HSA and Three Control Rabbits

\begin{tabular}{|c|c|c|c|c|c|c|c|}
\hline \multirow[b]{4}{*}{ Group } & \multirow[b]{4}{*}{ Rabbit } & \multicolumn{4}{|c|}{$\%$ DNA binding } & & \\
\hline & & \multicolumn{2}{|c|}{ Whole serum } & \multicolumn{2}{|c|}{ IgG fraction } & \multirow{2}{*}{\multicolumn{2}{|c|}{ Hydralazine antibody titer* }} \\
\hline & & & Single- & & Single- & & \\
\hline & & Native & stranded & Native & stranded & Whole serum & IgG fraction \\
\hline \multirow[t]{4}{*}{ I } & $\mathrm{I}-085$ & 9 & 44 & 8 & 53 & 1,280 & 32,768 \\
\hline & I-087 & 18 & 31 & 9 & 52 & 25,600 & 250,000 \\
\hline & I-095 & 53 & 41 & 51 & 65 & 12,800 & 8,192 \\
\hline & I-098 & 22 & 38 & 14 & 79 & 12,800 & 250,000 \\
\hline \multirow[t]{2}{*}{ II } & $\mathrm{I}-072$ & 8 & 7 & 1 & 4 & 32 & 0 \\
\hline & I-091 & 6 & 4 & 2 & 4 & 8 & 2 \\
\hline III & $\mathrm{I}-067$ & 6 & 4 & 2 & 4 & 2 & 2 \\
\hline
\end{tabular}

* Reciprocal.

In recent years, several investigators have presented evidence that there are small areas of single-strandedness in native DNA preparations obtained from both commercial and noncommercial sources $(18,19)$. Therefore, the native DNA preparation employed in these experiments (Worthington Biochemical Corp.) was subjected to enzymatic digestion with an exonuclease specific for single-stranded (heat-denatured) DNA as described in the Methods section. The enzyme-treated calf thymus DNA and a native calf thymus DNA which had been incubated and then dialyzed under similar conditions showed no differences in concentration of DNA as measured by UV spectroscopy. Both of these DNA preparations were then labeled with $\left[{ }^{3} \mathrm{H}\right]$ actinomycin D. Native DNA binding was determined with these two DNA's and a native DNA preparation prepared as used throughout this study. No significant differences in the binding between the three native DNA preparations were noted with four 20- or 22-wk sera and three $\operatorname{IgG}$ fractions obtained from animals in the hydralazine 25 -HSA group. These results were compared to sera and IgG fractions obtained from three control animals, and the findings were similar to that shown in Table VI. A melting curve of native calf thymus DNA (Worthington Biochemical Corp.) had all the characteristics of native DNA. Therefore, it would appear that the results obtained in this experiment for native DNA antibodies do represent antibodies against native DNA.

After $22 \mathrm{wk}$, the rabbits in each group were sacrificed and autopsies performed. No gross anatomical differences were noted between the various groups. Light microscopy showed no significant changes, except for one rabbit which exhibited slight thickening of the glomerular basement membrane. This was the rabbit in the hydralazine $25-\mathrm{HSA}$-immunized group which exhibited the highest native DNA binding activity. However, immunofluorescence of the kidneys of this rabbit and of all rabbits in each group were negative for the presence of $\mathrm{IgG}$ antibodies.

\section{DISCUSSION}

Because of the relationship of hydralazine to the induction of SLE in man and the need for a laboratory model of SLE, many investigators have sought to duplicate this clinical syndrome in animals. Such experiments have yielded a variety of results. Initally, in 1956, Comens reported the production of positive LE cells, renal glomerular lesions, (wire-loop), and some hematologic changes as well as cachexia, convulsions, and death in dogs receiving oral hydralazine (27). Symptoms occurred within a few weeks to a few months. Seven of the eight dogs had LE cells and in 2 cases the appearance of LE cells was confirmed by Hargreaves himself. However, neither Gardner nor Dubois et al. were able to reproduce this experiment except for the toxic reactions and some hematological abnormalities observed by Gardner $(28,29)$. LE-like cells were observed by Gardner but were very atypical, still retaining some nuclear structure. The same negative results were found by Möllerberg in rats and McCoy and Leach in pigs given oral hydralazine $(30,31)$. In 1958, Singuier et al., administering hydralazine orally, found that 4 of 15 guinea pigs developed "classic" LE cells, three others LE-"like" cells, anemia, and leukopenia, but the animals were not studied histologically (32). Braverman and Lerner in 1962 repeated this experiment, using a variety of regimens, but with most animals receiving $100 \mathrm{mg}$ hydralazine $/ \mathrm{kg}$ (33). $17 \%$ of the animals receiving 
hydralazine had LE-"like" cells in which the inclusion bodies were not homogeneous. On postmortem examination, no significant changes were noted except for minimal thickening of the glomerular basement membrane in some guinea pigs, but this finding was not considered to be significantly different from that observed in normal guinea pigs. In 1967, Leövey et al. administered hydralazine orally and intramuscularly incorporated in Freund's incomplete adjuvant to guinea pigs (34). Circulating antibodies to hydralazine could be demonstrated in $57 \%$ of the animals treated orally and in $71 \%$ of those receiving intramuscular injections, by a passive hemagglutination test using hydralazine alone as the antigen. Delayed hypersensitivity to hydralazine was also demonstrable in a large number of animals after a long period of treatment. ANA were found in $30 \%$ of the orally treated animals and $32 \%$ of the intramuscularly treated animals. LE cells were noted in a much smaller percentage. Histological changes consistent with lupus were possibly found in a few animals. No control animals were included in the study. Ellman et al., in 1971. administered hydralazine in CFA to guinea pigs in two injections 1 mo apart (35). They detected antibodies to hydralazine, using passive cutaneous anaphylaxis and the Farr technique employing ${ }^{125}$ I-hydralazines-ovalbumin. A marked strain difference was noted in that strain 2 guinea pigs were low responders whereas strain 13 and Hartley guinea pigs were high responders. Delayed hypersensitivity also developed to hydralazine. No differences were noted in the hepatic acetylation rate between strain 2 and strain 13 guinea pigs. ANA and anti-DNA antibodies were not found in this study. In 1972 and 1973, TenVeen and Feltkamp confirmed the earlier work of Cannat and Seligmann that hydralazine could induce ANA in mice (36-38). They studied three strains of mice with a variety of drugs known to induce an SLE-like syndrome in man, including hydralazine. Although all strains had a high spontaneous frequency of ANA, those receiving the drugs, including hydralazine, showed an earlier and higher incidence of ANA reactions. Immunoglobulin deposits were found in the kidneys of all mice treated and untreated and were unrelated to the ANA status. The deposits consisted of $\operatorname{IgG}, \operatorname{Ig} M$, and $C^{\prime} 3$. However, quantitatively, they thought that the mice receiving drugs had larger deposits. In addition, renal histology revealed an increase in mesangial cells and mesangial matrix, irregular thickening, protrusion of the outer sides of the basement membrane, and mononuclear cell proliferation. The same histological abnormalities were found in all mice but were more severe in the ANA-positive drug-treated mice compared to control mice. In summary, most prior experimental attempts to induce an SLE-like disease in animals with hydralazine were either completely nega- tive or produced results of equivocal significance. Undoubtedly, positive ANA was induced in some of these experiments, but in none was clear-cut clinical SLE produced, nor was there any data obtained which could explain the production of ANA by hydralazine.

In the present studies, the results obtained partially clarify this hitherto ill-understood relationship of hydralazine and SLE. A number of the problems concerning the mechanism of induction of SLE by hydralazine were at least in part resolved. First, hydralazine (and one of its major metabolites) was administered only as an immunogen, i.e., covalently attached to a carrier protein. This mode of presentation of hydralazine to the animal together with the fact that the total amount of hydralazine administered was miniscule (approximately $3.7 \mathrm{mg}$ total dose) would implicate an immune reaction to hydralazine as being responsible for the production of DNA antibodies rather than a "toxic" effect. Secondly, as apparent from inspection of the data on DNA antibodies (Figs. 2 and 3), continued immunization with hydralazine attached to a carrier was required, even while incorporating it in CFA. This need for hyperimmunization has been overlooked by many previous investigators and is in accordance with the observation that the average patient who develops hydralazine-SLE requires an average of 17 mo exposure to the drug (2). One difference found between this study and human drug-induced SLE is that the antibodies directed to DNA in the rabbits were to both the native and denatured forms. The amount of antibodies to native DNA produced in at least one rabbit was unexpectedly high. The conclusion that antibodies were produced to the native form of DNA is based on the results of DNA hemagglutination tests and binding of $\left[{ }^{3} \mathrm{H}\right]$ native DNA by the Farr technique as well as by specific inhibition of these tests. Further, the binding was confirmed to be to native DNA as demonstrated in the experiment where native DNA was treated with an exonuclease which is specific for single-stranded DNA. Similar results in the binding assay were also obtained with a highly purified deproteinized DNA.

Another major difference between the human druginduced disease and the findings in this experiment is that histological changes were not observed in the rabbits. However, this point must be qualified because the possibility exists that such changes might have appeared if the injections of hydralazine 25 -HSA and metabolitesHSA had been continued for a longer period of time. The antibody titers to both single-stranded and native DNA were continuing to rise when the experiment was terminated. Thirdly, the uncovering of the immunologic cross-reactivity existing between hydralazine and DNA is perhaps the most important observation made in this study. Initially this was suggested by the findings in 
double diffusion in agarose gel (Fig. 4) and confirmed by absorption studies of the DNA binding assays, inhibition of DNA hemagglutination tests by the hydralazine compounds and hydralazine itself, and finally by inhibition of hydralazine antibody titers by native DNA. The population of antibodies to DNA that are cross-reactive with hydralazine is likely to be quite small, as was suggested by the limited inhibition of hydralazine antibody titers with native DNA and by the thinness of the cross-reactive line between singlestranded DNA and hydralaziness-RSA noted in the double diffusion in agarose studies.

It is of interest that immunization with hydralazine linked to an isologous protein (RSA) failed to produce DNA antibodies but yielded hydralazine antibodies in amounts equal to those found in rabbits immunized with hydralazine attached to an heterologous protein (HSA). Because the hydralazine antibodies produced in the hydralazine ${ }_{25}$-RSA group were IgG antibodies and were hapten specific, it is suggested but not proven in these experiments that helper thymus-derived ( $\mathrm{T}$ ) lymphocytes were involved. Walters, Moorhead, and Claman have shown that haptens attached to an isologous carrier protein administered to mice in CFA are immunogenic involving helper $\mathrm{T}$ lymphocytes directed against both the hapten and the hapten-carrier conjugate but not against the carrier alone $(39,40)$. The question then arises as to why these antihydralazine antibodies in the hydralazine $25-\mathrm{RSA}$-immunized rabbits were not cross-reactive with DNA. One could postulate that there is a definite requirement for $\mathrm{T}$ lymphocytes directed against the carrier alone in order for a highly crossreactive population of hydralazine antibodies to be produced or that when such carrier directed $\mathrm{T}$ lymphocytes are activated, suppressor $\mathrm{T}$ lymphocytes which inhibit the production of antibodies to hydralazine which are cross-reactive with DNA are overcome. The data obtained in these experiments do not provide answers for these questions. They only emphasize the importance of an immune reaction occurring to a carirer protein.

The group of animals immunized with metaboliteHSA was smaller in number than that immunized with hydralaziness-HSA. However, the findings were quite similar. Antibodies induced by the metabolite crossreacted with hydralazine as well as with both the native and single-stranded DNA. Because the inhibition of the binding assay with hydralazinezs-RSA was quite similar to that found with metabolite-HSA, it is suggested that the antigenic determinant that induced DNA antibodies is common to both of these compounds. Most likely, this common antigen determinant resides in the similar phthalazine ring structure.

Although many problems concerning the relationship between hydralazine and DNA were resolved by this study, the question whether autoimmunity was truly established in the rabbits immunized with hydralazine $25-$ HSA and metabolite-HSA was not settled. Autoantibodies other than those directed against nuclear antigens were not sought. The antibodies to nuclear antigens which were detected may represent a subpopulation of antihydralazine antibodies which are cross-reactive with the nuclear antigens. This was suggested by the virtual complete removal of DNA binding activity in the sera of these rabbits by absorption of the sera with hydralazine or its compounds. It remains for $\mathrm{fu}-$ ture studies to resolve this point.

Extrapolation of the findings in this experiment can be made to human SLE. In accord with the theory of autoimmunity proposed by Weigle which is supported by his experimental observations, he has shown that for most self-antigens, $\mathrm{T}$ lymphocytes have a long duration of immune tolerance whereas in the bone marrow-derived (B) lymphocytes, the duration of immune tolerance is quite limited (41). B-cell clones are continually arising which can react with self-antigens if a $\mathrm{T}$-cell signal is given. Therefore, if the native antigen is altered or exposure is made to another closely related yet foreign antigen, tolerance to the native antigen is then abolished by $\mathrm{T}$-cell stimulation, and immune response with antibody production can ensue. A prime example of this is the induction of thyroiditis by Weigle. Rabbits have circulating low levels of thyroglobulin which he considers sufficient to maintain $\mathrm{T}$-cell unresponsiveness but not B-cell unresponsiveness (42). Therefore, clones of $\mathrm{B}$ cells responsive to thyroglobulin are continually arising. When he injected native thyroglobulin into rabbits, neither antibody formation nor thyroiditis occurred (43). If he injected altered or cross-reactive thyroglobulin into rabbits, then the rabbits not only made antibodies to thyroglobulin, but also thyroiditis appeared. Once the unresponsive state was terminated, further injections of thyroglobulin continued to increase antibody levels to thyroglobulin and the severity of thyroiditis (44). However, the antibodies produced were to antigenic determinants which were indigenous to the heterologous thyroglobulin since all the antibodies produced to thyroglobulin, even after injection of native thyroglobulin, could be completely absorbed with the heterologous thyroglobulin (45). If the injections of native thyroglobulin were continued, the rabbits soon regained tolerance to thyroglobulin. By applying this theory and the results of these experiments to hydralazine induction of SLE and using the data acquired in the present experiments, it would be expected that in humans, B-lymphocyte populations arise which are responsive to DNA but because of T-lymphocyte unresponsiveness, immune reactions do not occur. Hydralazine, as was demonstrated in these 
experiments, is cross-reactive with DNA. When it is administered to man orally, or to a rabbit by injection, antibody formation to hydralazine can occur with $\mathrm{T}$ lymphocytes being activated by hydralazine. Because of the cross-reactivity between hydralazine and DNA, immune reactions are mounted to DNA. However, the antibodies resulting from such immune reactions should be capable of being completely absorbed with hydralazine (according to Weigle's experiments) as they were in our experiments. This necessity for extensive T-lymphocyte activation was demonstrated by the failure to find DNA antibodies in rabbits immunized with hydralaziness-RSA. When hydralazine is discontinued in man or the injections stopped in rabbits, then tolerance to DNA eventually recurs. Although this point was not dramatically made in our experiments, the DNA antibody titers fell when the injections were discontinued for a period of $5 \mathrm{wk}$. If the injections had been permanently discontinued, the titers might have disappeared. In the human with hydralazine-induced SLE with discontinuation of the hydralazine, it would be expected, from Weigle's experiments, that the syndrome would remit, and this has usually been the case. In spontaneous SLE, the cross-reactive antigen(s), if it exists, is at present unknown.

The role of genetic factors was not evaluated in our experiments as the rabbits were outbred. However, hydralazine-induced human SLE may have genetic factors involved as it primarily occurs in Caucasians who are slow acetylators (2). Ongoing and future experiments in our laboratory are addressing this problem of possible genetic factors. It is hoped that this hydralazine-induced "serological SLE" may prove useful in future elucidation of the pathogenetic factors causing human SLE.

\section{ACKNOWLEDGMENTS}

The authors wish to acknowledge the following individuals: Dr. On Ja Kim for histology reports; Drs. J. Kokosa and J. Shah for metabolite work; and Mrs. F. Claes for expert technical assistance.

This work was supported by National Institutes of Health grant 3 RO1 AM 12297, the Geier Foundation, and the Ohio Valley Chapter of The Arthritis Foundation (Dr. Yamauchi).

\section{REFERENCES}

1. Condemi, J. J., S. E. Blomgren, and J. H. Vaughan. 1970. The procainamide-induced lupus syndrome. Bull. Rheum. Dis. 20: 604-608.

2. Perry, H. M., Jr. 1973. Late toxicity to hydralazine resembling systemic lupus erythematosus or rheumatoid arthritis. Am. J. Med. 54: 58-72.

3. Hahn, B. H., G. C. Sharp, W. S. Irvin, O. S. Kantor, C. A. Gardner, M. K. Bagby, H. M. Perry, Jr., and C. K. Osterland. 1972. Immune responses to hydralazine and nuclear antigens in hydralazine-induced lupus erythematosus. Ann. Intern. Med. 76: 365-374.

4. Condemi, J. J., D. Moore-Jones, J. H. Vaughan, and H. M. Perry, Jr. 1967. Antinuclear antibodies following hydralazine toxicity. N. Engl. J. Med. 276: 486-491.

5. Dammin, G. J., J. R. Nora, and J. B. Reardan. 1955. Hydralazine reaction: case with LE cells antemortem and postmortem, pulmonary, renal, splenic and muscular lesions of disseminated lupus erythematosus. J. Lab. Clin. Med. 46: 806.

6. Benton, J. W., B. Tynes, H. B. Register, Jr., C. Alford, and H. L. Holley. 1962. Systemic lupus erythematosus occurring during anticonvulsive drug therapy. $J$. Am. Med. Assoc. 180: 115-118.

7. Dustan, H. P., R. D. Taylor, A. C. Corcoran, and I. H. Page. 1954. Rheumatic and febrile syndrome during prolonged hydralazine treatment. J. Am. Med. As soc. $154: 23-29$.

8. Perry, H. M., Jr., and H. A. Schroeder. 1954. Syndrome simulating collagen disease caused by hydralazine (Apresoline). J. Am. Med. Assoc. 154: 670-673.

9. Friedman, H., and W. I. Heine. 1963. Demonstration of anti-hydralazine antibody in hydralazine induced lupus erythematosus. Experentia (Basel). 19: 10-11.

10. Litwin, A., L. E. Adams, E. V. Hess, J. McManus, and H. Zimmer. 1973. Hydralazine urinary metabolites in systemic lupus erythematosus. Arthritis Rheum. 16: 217-220.

11. Shevky, M. C., and D. D. Stafford. 1923. Clinical method for estimation of protein in urine and other body fluids. Arch. Intern. Med. 32: 222-225.

12. Zimmer, H., J. McManus, T. Novinson, E. V. Hess, and A. Litwin. 1970. A major metabolite of 1-hydrazinophthalazine. Arzneim.-Forsch. 20 : 1586-1587.

13. J. Kokosa. 1973. Ph.D. Thesis. University of Cincinnati, Cincinnati, Ohio.

14. Boyden, S. V. 1951. The adsorption of proteins on erythrocytes treated with tannic acid and subsequent hemagglutination by anti-protein sera. J. Exp. Med. 93: $107-120$.

15. Sever, J. L. 1962. Application of a microtechnique to viral serological investigations. J. Immunol. 88: 320-329.

16. Carr, R. I., D. Koffler, V. Agnello, and H. G. Kunkel 1969. Studies of DNA antibodies using DNA labelled with actinomycin-D $\left({ }^{3} \mathrm{H}\right)$ or dimethy $\left({ }^{3} \mathrm{H}\right)$ sulfate. Clin. Exp. Immunol. 4: 527-536.

17. Marmur, J. 1961. A procedure for the isolation of deoxyribonucleic acid from micro-organisms. J. Mol. Biol. 3: 208-218.

18. Tan, E. M., and P. G. Natali. 1970. Comparative study of antibodies to native and denatured DNA. J. Immunol. 104: 902-906.

19. Winfield, J. B., and J. S. Davis, IV. 1974. Anti-DNA antibody in procainamide-induced lupus erythematosus. Arthritis Rheum. 17: 97-110.

20. Rabin, E. Z., B. Preiss, and M. J. Fraser. 1971. A nuclease from Neurospora crassa conidia specific for single-stranded nucleic acids. Prep. Biochem. 1: 283307.

21. Rabin, E. Z., H. Tenenhouse, and M. J. Fraser. 1972. An exonuclease of Neurospora crassa specific for singlestranded nucleic acids. Biochem. Biophys. Acta. 259: $50-68$.

22. Tan, E. M., and H. G. Kunkel. 1966. Characteristics of a soluble nuclear antigen precipitating with sera of patients with systemic lupus erythematosus. J. Immunol. 96 : 464-471. 
23. Inami, Y. H., R. M. Nakamura, and E. M. Tan. 1973. Micro-hemagglutination tests for detection of native and single-strand DNA antibodies and circulating DNA antigen. J. Immunol. Methods. 3: 287-300.

24. Sober, H. A., F. J. Gutter, M. M. Wyckoff, and E. A. Peterson. 1956. Chromatography of protein. II. Fractionation of serum protein on anion-exchange cellulose. J. Am. Chem. Soc. 78: 756-763.

25. Snedecor, G., and W. B. Cochran. 1967. Statistical Methods. Iowa State University Press, Ames, Iowa. 6th edition. 91.

26. Harbeck, R. J., E. J. Bardana, P. F. Kohler, and R. I. Carr. 1973. DNA: anti-DNA complexes: their detection in systemic lupus erythematosus sera. J. Clin. Invest. $52:$ 789-795.

27. Comens, P. 1956. Experimental hydralazine disease and its similarity to disseminated lupus erythematosus. $J$. Lab. Clin. Med. 47 : 444-454.

28. Gardner, D. L. 1957. The response of the dog to oral 1-hydrazinophthalazine (hydralazine). Br. J. Exp. Pathol. 38: 227-235.

29. Dubois, E. L., Y. J. Katz, V. Freeman, and F. Garbak. 1957. Chronic toxicity studies of hydralazine (Apresoline) in dogs with particular reference to the production of the "hydralazine syndrome." J. Lab. Clin. Med. 50: 119-126.

30. Möllerberg, H. 1958. Attempts to produce the "hydralazine syndrome" in the albino rat. Acta Med.Scand. $161: 443-445$.

31. McCoy, F. W., and W. J. Leach. 1959. Experimental attempt to produce the L-E. syndrome (arthritis) in swine with hydralazine. Proc. Soc. Exp. Biol. Med. $101: 183$.

32. Singuier, F., C. Betourné, and J. Bonnet de la Tour. 1958. Hydralazine lupus erythematosus. Sem. Hop. Paris. 34: 773-784.

33. Braverman, I. M., and A. B. Lerner. 1962. Hydralazine disease in the guinea-pig as an experimental model for lupus erythematosus. J. Invest. Dermatol. 39: 317-327.

34. Leövey, A., G. Szegedi, J. Borbory, and I. Dévényi. 1967. Experimental "hydralazine erythematodes" of the guinea pig. Acta Rheumatol. Scand. 13: 119-136.
35. Ellman, L., J. Inman, and I. Green. 1971. Strain difference in the immune response to hydralazine in inbred guinea-pigs. Clin. Exp. Immunol. 9: 927-937.

36. TenVeen, J. H., and T. E. W. Feltkamp. 1972. Studies on drug induced lupus erythematosus in mice. I. Drug induced antinuclear antibodies (ANA). Clin. Exp. Immunol. 11 : 265-276.

37. TenVeen, J. H., and T. M. Feltkamp-Vroom. 1973. Studies on drug-induced lupus erythematosus in mice. III. Renal lesions and splenomegaly in drug-induced lupus erythematosus. Clin. Exp. Immunol. 15: 591-600.

38. Cannat, A., and M. Seligmann. 1968. Induction by isoniazid and hydralazine of antinuclear factors in mice. Clin. Exp. Immunol. 3: 99-105.

39. Walters, C. S., J. W. Moorhead, and H. N. Claman. 1972. Immunity and tolerance to a hapten (NIP) coupled to an isologous carrier (mouse gammaglobulin). J. Exp. Med. 136: 546-555.

40. Moorhead, J. W., C. S. Walters, and H. N. Claman. 1973. Immunologic reactions to haptens on autologous carriers. I. Participation of both thymus-derived and bone marrow-derived cells in the secondary in vitro response. J. Exp. Med. 137: 411-423.

41. Chiller, J. M., G. S. Habicht, and W. O. Weigle. 1971. Kinetic differences in unresponsiveness of thymus and bone marrow cells. Science (Wash. D. C.). 171: 813815.

42. Weigle, W. O. 1973. Immunological unresponsiveness. Adv. Immunol. 16: 61-122.

43. Nakamura, R. M., and W. O. Weigle. 1967. Induction, maintenance and termination of immunologic unresponsiveness to bovine thyroglobulin in rabbits. J. Immunol. 99: 357-364.

44. Weigle, W. O. 1965. The production of thyroiditis and antibody following injection of unaltered thyroglobulin without adjuvant into rabbits previously stimulated with altered thyroglobulin. J. Exp. Med. 122: 1049-1062.

45. Weigle, W. O., and R. M. Nakamura. 1967. The development of autoimmune thyroiditis in rabbits following injection of aqueous preparations of heterologous thyroglobulins. J. Immunol. 99: 223-231. 